\title{
Pere Rovira a lo largo
}

Eduardo López Truco

Me gusta pensar que Pere Rovira nos permitió entroncar con la tradición de los grandes maestros literarios, que primero también lo fueron suyos. Discípulo de José Manuel Blecua, se doctoró sobre la obra de Gil de Biedma, otro de los grandes lectores de su generación, con alguno de los cuales, como José Agustín Goytisolo, compartió amistad y ceniceros de discusiones. Éste, que había asistido a las clases de Dámaso Alonso junto a Ernesto Cardenal y José Coronel Utrecho, nos contaría en más de una ocasión cómo el Director eterno de la RAE le habría aceptado las ausencias a sus clases si a cambio dedicaba ese tiempo a leer. Lo importante era leer. Leer. "Usted, lea, joven, lea", decía Goytisolo imitando con un hilillo de voz al maestro del poema del río llamado Carlos.

Ese es el vínculo al que me gusta creer que Pere Rovira, con su ejemplo y su labor docente y literaria, nos permitió sumarnos. La formación de un lector es una tarea que va más allá del periodo de formación universitaria, aunque empieza a gestarse en esta etapa, si no antes. Ese es un plazo de tiempo relativamente breve como para poder asumir un criterio diferenciado propio o, al menos, personal. $Y$ en consecuencia, guardo el recuerdo de mi deslumbramiento ante muchos de los autores que en aquellos ańos nos visitaron, gracias a su amistad con Pere, sobre todo por su visión literaria del mundo y su asunción del legado literario de una lengua que, como el país, estaba redescubriendo el mundo de a pie. Y me refiero en especial a los más jóvenes, que empezaban sus obras y en las cuales él supo captar la calidad y el bagaje que las habían hecho posibles. Pere nos puso sobre el mapa. Y nos sumó a su tradición, la que en aquellos años se estaba gestando con esa nueva generación de escritores y poetas, nos permitió conocerla, compartir sus encuentros, ser parte de ese pequeño pueblo en armas contra la soledad. 
Es fácil decir todo esto - se me dirá. Pero quiero insistir en el yermo cultural que debió encontrarse Pere, y también todos aquellos que arrancaron con las clases de Filología Hispánica en el vetusto y enyesado Estudi General del Roser. Nosotros llegamos cuando aún no se habrían secado los ríos de sangre académica vertidos por el caso de La Higiénica. E imagino que un cierto aire de fatiga mental vagaría por el edificio tras la repercusión que había originado la publicación de un poema. Era 1983, y ya digo que hacía nada que se habían paseado los tanques por Valencia como por el pasillo de su casa, y los restaurantes de nuestra ciudad habían acogido el ruido de tenedores y cuchillos del Gobernador Militar dictando su placet.

Quiero pensar que el Departamento de Literatura Hispánica de la Facultad se les hacía pequeño a Pere y a sus colegas Jaume Pont, Jordi Jové y Paco Tovar. Alguna vez que metí la cabeza en uno de sus despachos lo vi atestados de papeles, apuntes, trabajos, libros, posters, fotos... No hubo curso en que no se apoyaran las iniciativas de nuevas revistas alimentadas por el fervor del puñado de iluminados que toda promoción acoge. La bonanza económica de la facultad, generada por el número desbordante de alumnos, favorecería la realización de actividades que hasta entonces nunca antes habían tenido lugar en la pequeña ciudad lejana donde nunca se cruzaban los caminos. Y ahí es donde se empezó a fraguar el sueño de Pere Rovira cuando imaginó una realidad que no existía a su alrededor y que él creyó que podía llegar a existir si le añadía un poco de todo lo mejor que había ido conociendo en París, en Granada, en Barcelona, en Bilbao, en Oviedo, en Málaga...

Lleida pasó de figurar en un lugar relevante en el mapa de la nada a ser una ciudad en la que pasaban cosas. Pasaba gente. Y quienes no habían venido nunca deseaban visitarnos y conocernos. Siempre hubo un aula llena de alumnos para acoger a los invitados. Y las horas se llenaban de preguntas, debates, coloquios y proseguían más allá de las aulas y se adueñaban del tiempo y de las noches. Las listas son ociosas. Para eso trabaja la memoria guardando página aparte en un atlas que a partir de entonces empezó a señalar lugares comunes con nombres propios. Tengo por cierto que, como el viajero en el tiempo de un célebre relato de Ray Bradbury, si regresara a un momento de 1988 y paseara por la ciudad, Lleida y su pulso cultural serían muy diferentes tan solo porque Pere se salió del guion.

Hay un Quijote antes y después de sus palabras, como un Espronceda y un Larra, un Quevedo o la relectura de la obra de la generación del 27 a partir de cómo la recibieron los autores de los 50 . Y lo curioso es que los profesores y escritores que se acercaban a nuestras aulas no hacían sino corroborar sus palabras y ampliarlas con sus nuevas lecturas e investigaciones, propiciando un verdadero entramado virtual que obedecía a las leyes de la fe literaria y de la amistad. Su ejemplo marcó decisivamente, junto con el de Fernando Rocaspana, mi vocación y mi manera de entender la literatura, su función social y la tarea de un profesor. Uno no escoge a sus maestros por más que se empeñe. Son estos quienes se apoderan de uno por medio de sus palabras, de sus lecciones, de sus actos, de su personalidad, de su inteligencia. 
Hemos mantenido nuestra amistad a lo largo de los años, que siempre he procurado vestir con respeto y admiración. Como en los versos que cierran el poema que Ausoni dirige a su amigo Dinami, me gustaría pensar que quienes escuchamos sus palabras e hicimos nuestra su tradición fuimos dignos de su memoria. 